\title{
3. 新しい放送型サービスの提案
}

\section{3-2. MediaFLO事業の現状と動向}

\section{猪澤伸悟 ${ }^{\dagger}$, 川嶋裕幸 ${ }^{\dagger}$}

キーワードロ 携帯電話, デジタル放送, マルチメディア放送, マルチキャスト

\section{1 ま え がき}

日本でワンセグ (ISDB-T: Integrated Services Digital Broadcasting-Terrestrial) サービスが開始され約 2 年が経過 した，世界各国においてもワンセグ同様, 携帯端末向けの デジタル放送方式として欧州のDVB-H (Digital Video Broadcasting for Handheld), 韓国のT-DMB (TerrestrialDigital Media Broadcasting)/S-DMB (Satellite-Digital Media Broadcasting), 米国のATSC-M/H (Advanced Television Systems Committee-Mobile Handheld), MediaFLO (Forward Link Only) などのさまざまな方式が 考案され, それぞれが商用サービスの提供を開始し, また は，その準備を進めている。

各方式は周波数スペクトラムの有効利用, ノイズ・マル チパス対策, 低消費電力対策, 移動時のローミング切替え (SFN: Single Frequency Network, MFN: Multi Frequency Network)）などに各々特徵があり, 各国の電波政策や規制, 広告モデルや有料番組モデルなどのビジネス形態, コンテ ンツ, 視聴形態, 価值観や経済力などのさまざまな要素, 条件に基づいたサービスに対応する設計が施されている.

ここでは，通信分野から派生したモバイル向けマルチメ ディア放送であるMediaFLOの標準化の状況, 国内外の動 向，実現に向けた課題について説明する.

\section{MediaFLOの概要}

\section{1 サービスの特徵}

MediaFLOの占有周波数は $5,6,7,8 \mathrm{MHz}$ 幅の中から一つ を選択することができ，この周波数帯域を単位とする統計 多重技術 (後述) を用い, 約22番組 (映像：Enhanced H.264, 最大30fps, 音声 : MPEG-2 AAC HE, 6MHz幅の場合) を提 供することができる．また，ストリーミング番組の他に， クリップキャスティングとIPデータキャスティングを用いて さまざまな形態のコンテンツを提供することができる.

$\dagger$ KDDI研究所 開発センター

"Trend on MediaFLO Technology and Buisiness" by Shingo Izawa and Hiroyuki Kawashima (Technology Development Center, KDDI R\&D Laboratories Inc., Tokyo)

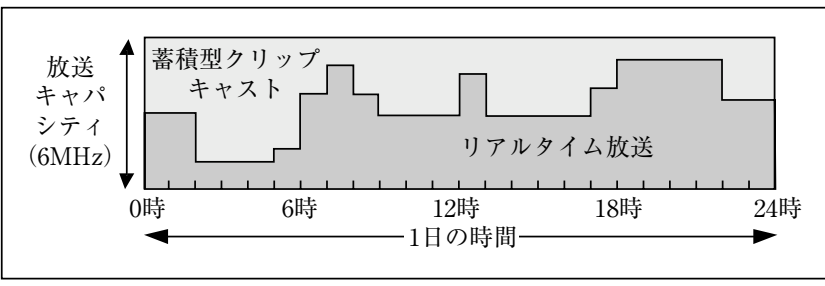

図 1 リアルタイム番組と蓄積型コンテンツの配置例

クリップキャスティングは視聴中もしくは待ち受け中に バックグラウンドで蓄積受信したコンテンツを好きなとき に再生できるというもので，地下街などの電波遮蔽空間や 空き時間の暇つぶし視聴などの利用シーンを想定したサー ビスである.

IPデータキャスティングは, MediaFLOのダウンリンク を用いてデータパケットをプッシュ型のマルチキャストで 届ける仕組みである。すでに通信端末として具備されてい るIPプロトコルスタックを利用するため, MediaFLOアプ リケーション専用のプロトコルスタックを用意する必要が なく，サーバ (放送)・クライアント(端末アプリケーショ ン) 間でプロトコルを規定するだけで必要なデータを簡単 にマルチキャスト伝送することができる，また，同じIPプ ロトコルスタックを使い $3 \mathrm{G}$ 通信ネットワークに接続するこ とにより，インタラクティブ通信や，コマースサイトへの 連携や着うたフルなどのコンテンツ購入などの機能を簡単 に搭載し連携することができる.

MediaFLOではストリーミング，クリップキャストおよ びIPデータキャスティングなどのさまざまなコンテンツを 放送キャパシティの枠内でダイナミックに多重化 (統計多 重 (図1))することにより, セグメント単位で分割する放送 方式と比較し，挿入されるNullパケットを削減することが できるため, 効率の良い番組編成が可能となる (図2).

\section{2 無線方式の特徵}

MediaFLOのフレーム (図3)では，コンテンツのペイロ ードの位置 (う論理チャネル) をフレームの先頭に配置され たOIS (Overhead Information Symbol) 内のスーパーフレ ームの構成情報により管理しており, 受信端末はスーパー フレームの先頭に配置されたOISを受信することで，コン 


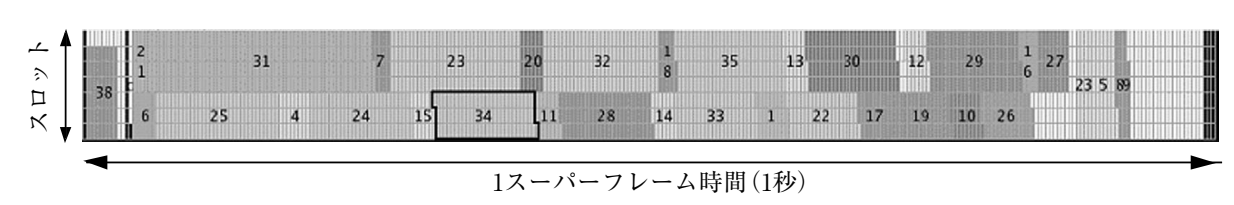

番号は論理チャンネル (MLC) のID. 各番組はその情報量に応じて各MLCがダイナミックに配置される

図2 統計多重と番組の配置

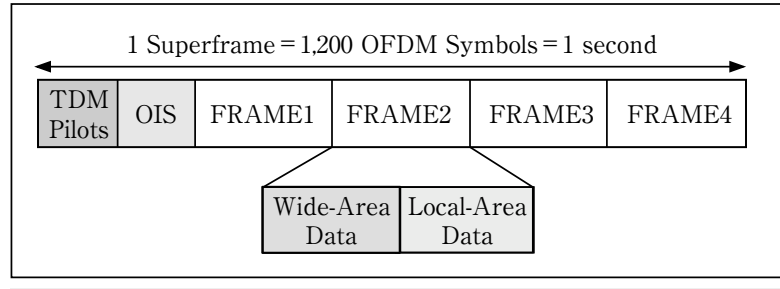

図3ＭediaFLOのスーパーフレーム構造（6MHz幅の場合）

テンツの位置を特定する。表1のmode=5にあるとおり， OIS情報には低い所要C/N (=対ノイズ性に優れる)の変調 パラメータが設定されている. MediaFLOのスーパーフレ ームでは, 論理チャネル毎に異なる符号化率と変調方式を 設定できるため, サービスやコンテンツ, ユーザの利用シ ーンにあわせた方法でコンテンツを届けることができる.

視聴番組の切替えはOISが指し示す論理チャネルを切替 えるだけであり, 他の放送方式と比較し番組切替えの応答 レスポンスが良いことが特徴である. また，複数の論理チ ヤネル (番組) を同時に受信することもでき, 裏番組の録画 や，バックグラウンドでのコンテンツダウンロードなども 一つのチューナで実装搭載することができる.

MediaFLOのチューナは, 視聴していない論理チャネル の受信処理を行わないことで消費電力を削減している.こ の何も受信処理しない (NULL) 状態による消費電力削減方 法は携帯電話端末の仕組みを生かしたものである.

MediaFLOの変調方式と伝送レートを表1に示す.レイヤ ードモジュレーション（表1のmode=6〜11 Layered）は， 電波受信状況に応じた品質の映像データを受信するための 仕組みである。

\section{MediaFLOの標準化動向と世界動向}

\section{1 標準化動向}

FLO Forumは，2005年7月にQualcommを中心に携帯端 末向けマルチメディア放送の標準化と普及活動を推進する 団体として設立され, インフラ・端末メーカ, 通信事業者, サービスプロバイダ, アプリケーションベンダ, 学術団体 により構成された 93 社 (2007年12月現在) が国際標準仕様の 策定を推進している.すでに, アメリカ電気通信工業会 (TR-47.1) において, 無線インタフェース（AIS (Air Interface Specification) TIA-1099, TIA-1120), FLOデバ イス（TIA-1102），FLO送信機および検証（TIA-1103）, FLOアプリケーション（TIA-1104）の承認を取得しており, ITU-Rでの针告化 (Multimedia System M) も完了している.
表1 MediaFLOの変調方式と伝送レート

\begin{tabular}{|c|c|c|c|}
\hline Mode & Modulation & Inner Code Rate & Data Rate (Mbps) \\
\hline \hline 0 & QPSK & $1 / 3$ & 2.8 \\
\hline 1 & QPSK & $1 / 2$ & 4.2 \\
\hline 2 & $16 Q A M$ & $1 / 3$ & 5.6 \\
\hline 3 & $16 Q A M$ & $1 / 2$ & 8.4 \\
\hline 4 & $16 Q A M$ & $2 / 3$ & 11.2 \\
\hline 5 & QPSK & $1 / 5$ & for OIS \\
\hline 6,9 & Layered & $1 / 3$ & 5.6 \\
\hline 7,10 & Layered & $1 / 2$ & 8.4 \\
\hline 8,11 & Layered & $2 / 3$ & 11.2 \\
\hline
\end{tabular}

これらTIA標準に従い，2007年3月にMediaFLO USA（オ ペレータ) がUHF54ch (716-722MHz) の全国免許で放送を 行い, Verizon WirelessがV CAST Mobile TVのブランド でサービスを提供している。放送提供エリアは2007年末よ り全米の主要都市をすべてカバーしている.

現在, FLO Forumでは, 欧米向けL-Band, S-Band, 日 本向けのVHF High-Bandなどにおける電波伝搬特性を考慮 した変調パラメータ (AIS Revision2.0) の適用を検討して いる.これにより，オペレータはOFDM (Orthogonal Frequency Division Multiplexing) サブキャリヤ数やガー ドインタバルなど, パラメータの選択が可能となり, リン クバジェットの拡大, マルチパス対策, 伝送帯域の広帯域 化が可能となる.

\subsection{CAS (Conditional Access System)}

CASは，有料放送を提供する上で必須となるコンテンツ 保護システムである。番組を視聴するために必要な鍵 (CWs: Control Words) は, 契約に基づく鍵（EMMs: Entitlement Management Messages) やサービスに基づく 鍵 (ECMs: Entitlement Control Messages)により多重に施 錠されている，通信機能を持つ受信端末では，セキュア通 信を使用しEMMを交換することができる．また，同様に ECMを通信で交換することにより，Pay-Per-Viewなどのき め細かな料金プランやサービスを用意することができる.

携帯端末では移動環境での使用が前提となるため, 移動 先での各事業者との提携や, ケーブルテレビ, 固定テレビ などとの連携による「相互乗り入れ視聴」が期待されている. FLO Forumでは, サイマルクリプト (Simul Crypt：異な るアルゴリズムにより生成された鍵を束ねて送信し，受信 端末の対応アルゴリズムで開錠する仕組み) の導入を推進 しており，複数事業者間の連携により，日本のMediaFLO サービスの加入者が米国のMediaFLOや， ヨーロッパの 
DVB-Hなどの放送番組を，日本の加入契約で楽しむことな どが可能となる.

\section{3 携帯端末向けマルチメディア放送の世界動向}

日本と同様欧州においても固定アナログテレビのディジ タル移行作業が進められており，これにより生まれた空き 周波数 (UHFバンド) を利用した隽帯端末向けのマルチメ ディア放送サービス (DVB-H) の導入が進んでいる.

DVB-Hは欧州におけるデジタル放送の標準化団体DVB (Digital Video Broadcasting Project) が策定した携帯端末向 けの地上デジタル放送の仕様で, 時分割で番組を多重送信*1 （タイムスライス，バースト送信）と受信処理を間欠受信に より端末の消費電力を抑制することに特徵がある（欧州電 気通信標準化機構 (ETSI: European Telecommunications Standards Institute) によって，2004年11月に承認).

DVB-Hには周波数, 変調パラメータや符号化方式 (H.263/H.264, MP3/AAC), CAS方式など, 規制や端末機 能に差異があり, 各国DVB-Hのサブセット仕様で運用して おり相互互換性の確保が課題である.

英国ではUHF bandに空きがないため, MediaFLOでは 再利用が可能になる2012年までの間, L-BandまたはSBandでのサービス提供を検討している. また，BTと Virgin Mobileが共同でDAB-IP仕様によるモバイルTVの実 証実験 (Band III 220MHz) を行っている.

ドイッではDVB-Hの放送に必要なUHF bandの確保が難 しく, 必要となる帯域幅の狭いDMB (1.536MHz幅) が先行 して放送されている.

韓国では2005年にDMB方式による地上デジタル放送 (TDMB) と衛星デジタル放送 (S-DMB)を開始している。TDMBは六つの放送事業者により首都圈で無料放送を, SDMBは通信事業者により韓国全域で有料放送サービス提 供している．また，韓国の端末メーカはイギリス，ドイッ， フランス，イタリアなどで韓国の国産技術であるDMBの プロモーション活動を積極的に進めている.

\section{4 通信インフラによるマルチキャスト配信技術}

KDDIは電話やデー夕回線の一部帯域を用いて, 同じコ ンテンツを多数のユーザに同報配信する BCMCS (Broadcast Multicast Services) サービスを2003年に開始し た. BCMCSの提供エリアは広い(携帯電話のエリアと同等) が，携帯電話インフラと伝送帯域をシェアしていることも あり，大容量コンテンツの配信は夜間に行うなど，放送サ ービスというょりはむしろ，蓄積型配信サービスと言える ものである. その後, 2006年9月にEV-DO Rev. A*2導入に あわせて「EZチャネルプラス」，「EZニュースフラッシュ」 などサービス拡充を行っている.

W-CDMAにおいても同様3GPPがマルチキャスト配信サ ービスをMBMS (Multimedia Broadcast and Multicast

*1 MediaFLOは, 夕イムスライスと周波数分割の併用.

*2 CDMA2000 1xEV-DO Revision A (IS-856-A) Revision Aにより, パケ ット通信速度が下り最大 $3.1 \mathrm{Mbps}$ ，上り最大 $1.8 \mathrm{Mbps}$ に高速化した.

$680(48)$
Service）として規格化しているが，日本国内での商用化に は至っていない.

欧州ではTD-CDMA (Time Division-Code Division Multiple Access：時分割複信-符号分割多元接続) 技術を用 いたMBMSサービス（TDtv）が提供されている．TDCDMAは，上下回線の伝送帯域を時分割することで双方向 通信を行う方式であり，TDtvでは通信とは別の帯域を下 り回線に割当ててマルチキャスト配信を行っている.

$\mathrm{TDtv}$ のメリットはマルチキャスト用のヘッドエンドを 既存のTD-CDMAで構成された通信設備と共存させること で, 設備構築のコストを削減できるところにあり，方式と してはBCMCSとMediaFLOの中間に位置するものと考え られる。

\section{4 日本におけるMediaFLOの状況と課題}

\section{1 通信端末と放送端末の変遷}

携带電話の第一世代は1988年NTTとIDOによるHiCAP方 式*3，1989年DDI/IDOによるJTACS/NTACS方式 (英国の TACS (Total Access Communication System)*4を日本向 けの周波数に適合させた方式）によりサービスが開始され， 1993年のPDC (Personal Digital Cellular) およびcdma (Code Division Multiple Access) の第二世代，IMT-2000に よるW-CDMAやCDMA 1X (CDMA2000 1x) の第三世代を 経て, さらに高速なデー夕通信を実現するHSPA, HSPA+ などに向け，約10年間隔で世代交代を行ってきている.

一方, テレビ放送の歴史は古く, 1953年に日本で初めて 白黒放送が開始され，1960年にカラー放送，1989年にBS衛 星，2003年にデジタル放送が開始されている。現在，世界 的規模でデイジタル方式への移行が進められている.

2006年4月にワンセグ*5が開始され，放送を受信する携 帯電話端末が登場した。この端末は放送, 通信, 組达み機 器，ブラウザや通信アプリケーションの技術を集結したも のであり，通信と放送の技術が融合した端末といえる.

\section{2 受信端末とネットワークの共存}

地上デジタル放送の受信チューナデバイスはSoC (System on a Chip) 技術により, アンテナやフィルタなど を除く部品のほとんどが一つのプラスチックパッケージに 収さめられ, 小型化, 低消費電力化, 部品数の削減が進ん でいる. また, MediaFLOとDVB-HやISDB-Tなどの複数 放送システムへの対応も進められている。これにより，千 ユーナチップの回路数や複雑度は増加する傾向にあるが, プロセス加工技術の進化によりチップサイズや消費電力は 逆に小さくなっている，送信機のパワーアンプ，アンテナ 鉄塔などの設備も各システム基本構成は同じであり, 転用 が可能となっている.

*3 High Capacity方式, NTTが開発.

*4 AMPS (Advanced Mobile Phone System : AT\&T・モトローラ方式) を元に欧州向けに開発.

*5 携帯電話・移動体端末向けの1セグメント部分受信サービス. 


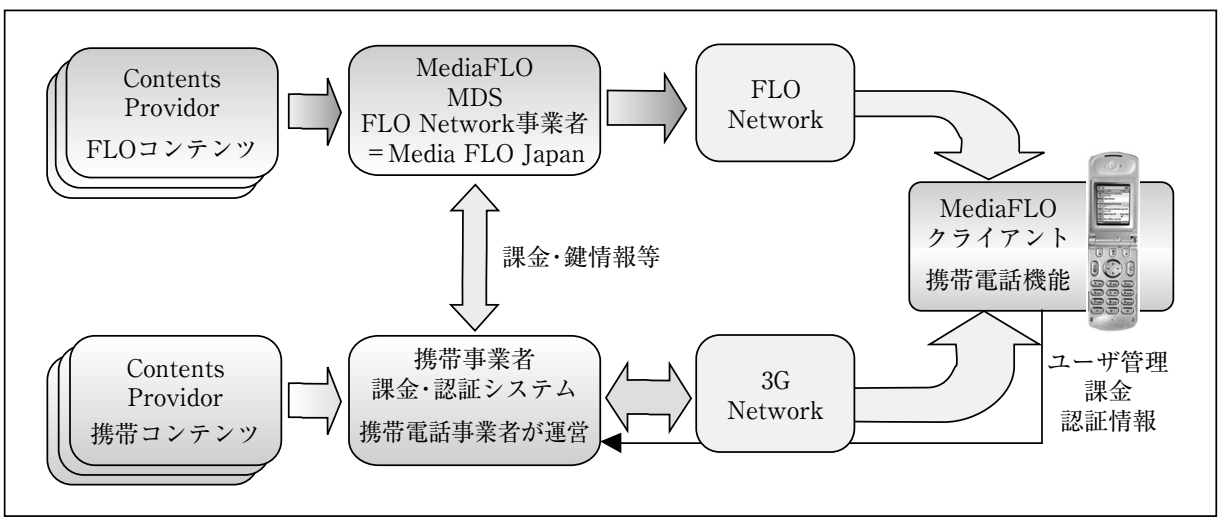

図4 MediaFLOのビジネスモデル

また，MediaFLOネットワークの特徵はヘッドエンドで 通信の課金システムと密接に接続されており（図4）, MediaFLOでは携帯電話事業者の課金インフラを最大限に 利用し有料放送サービスを提供することが可能である。ま た，1億台を超える携帯電話端末 (ワンセグ搭載機は 1,500 万 台以上が出荷) の規模で事業の展開が可能である.

\section{3 メディアフロージャパン企画の活動概要}

2005年12月，KDDIとクアルコムはメディアフロージャ パン企画 (以下, MJP) を設立し, MediaFLOの市場性や事 業性の検証，周波数獲得への取組みを進めている.

2006年秋にMJPが実施した「携帯電話向けの有料多チャ ネル放送の受容性に関するアンケート調査 (インターネッ 卜調査：サンプル数 3000 , 対面インタビュー形式：サンプ ル数227)」では, MediaFLOの画質やユーザビリティは高 い評価を得ている。利用シーンは, 街, 会社, 自宅などで の暇つぶしが高いポイントを示した。ささらに, 地下，屋内 での受信に対するニーズが強く, 広範囲なジャンルの番組 提供に関心が高かった。 また，同時期に実施したシールド ルームでの電波干渉実験データを基に, $\operatorname{UHF}(716-722 \mathrm{MHz})$ による屋内電波伝搬実験, 画質 - 音声品質や切替え機能お よび，IPデータキャスティングのアプリケーション動作実 験をKDDIデザイニングスタジオ（原宿）で進めており，今 後は規模を拡大し屋外での実験なども検討している. 本実 験では映像品質や選局切換えなどの操作性, IPデータキャ スティングなどの動作実験だけではなく, 広くご意見やご 感想を頂く予定である.

また，総務省が主催する「携帯端末向けマルチメディア 放送サービス等の在り方に関する懇談会 (通称, MM懇談 会)」において, 免許主体, 免許の単位など免許の在り方を 始めとする制度分野，適用すべき技術方式，想定ビジネス モデル, 国際競争力強化, 視聴者が期待するマルチメディ ア放送について，広く事業者等からヒアリングを行いなが ら議論が行われている.

MJPでは，MediaFLOが次世代の携帯向けマルチメディ ア放送を担うことができる，方式の一つであると考え， MM懇談会への提案活動やユビキタス特区制度を活用した 実証実験を通じ，事業化に向けた活動を推進している.

\section{5 むすび}

日本では携帯端末でのデジタル放送を受信することは “あたりまえ”になりつつあり，世界各国においても「デジ タル放送の推進」と「組达み技術の高度化」により，今まで にないスピードで普及が進んでいる.

MediaFLOはこのデジタル放送を超える，広帯域の片方 向リンク (Forward Link) とIPマルチキャスト通信の融合 ネットワークを実現する技術として，さらに発展し進化し ていくものと考えている.

(2008年1月21日受付)

\section{〔文 献〕}

1) 前田：“携帯電話向け多チャネル放送サービスMediaFLO”，映情学誌， 60, 5, pp.725-727 (2006)

2) TIA-1099 Forward Link Only Air Interface Specification for Terrestrial Mobile Multimedia Multicast,

3) TIA-1102 Minimum Performance Specification for Terrestrial Mobile Multimedia Multicast Forward Link Only Devices

4) TIA-1103 Minimum Performance Specification for Terrestrial Mobile Multimedia Multicast Forward Link Only Transmitters

5) TIA-1104 Test Application Protocol for Terrestrial Mobile Multimedia Multicast Forward Link Only Transmitters and Devices

6) TIA-1120 Forward Link Only Transport Specification

7) IEEE Transactions on Broadcasting, Vol. 53 No.1 March 2007

8) http://www.floforum.org/

9) http://www.dvb-h.org/

10) http://www.worlddab.org/

11) http://www.soumu.go.jp/

12) http://www.arib.or.jp/

13) http://www.tca.or.jp/

14) http://www.qualcomm.com/

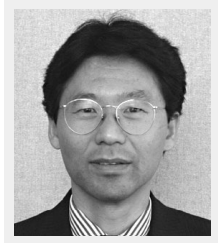

猪澤 伸悟 1986 年, 慶應義塾大学大学院工学研 究科修士課程修了, 同年, KDD (株) (現 KDDI (株)) 入社. 主に，モバイル\&IPソリューション分野，通信 放送連携分野，ユビキタス分野に関する技術開発およ び商品開発に従事.

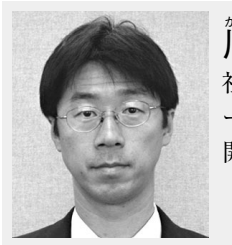

乫岘嶋裕幸 1986 年, KDD (株) (現 $\mathrm{KDDI}$ (株)) 入 社. 主に, 電話・ISDN交換サービス, WEBアプリケ ーション開発，マルチメディア放送分野に関する技術 開発拄よび商品開発に従事. 